\title{
P2X7 gene polymorphisms and risk assessment for pulmonary tuberculosis in Asian Indians
}

\author{
Venkatasubramanian Sambasivan $^{\mathrm{a}}$, Kolluri Janaki Rama Murthy ${ }^{\mathrm{b}}$, Ravindra Reddy ${ }^{\mathrm{e}}$, \\ Valluri Vijayalakshimi ${ }^{\mathrm{b}, \mathrm{c}}$ and Qurratulain Hasan ${ }^{\mathrm{a}, \mathrm{d}, *}$ \\ ${ }^{a}$ Department of Genetics, Bhagwan Mahavir Medical Research Centre, 10-1-1, A.C. Guards, Hyderabad, 500004, \\ India \\ ${ }^{\mathrm{b}}$ Department of Immunology, Bhagwan Mahavir Medical Research Centre, 10-1-1, A.C. Guards, Hyderabad, \\ 500004, India \\ ${ }^{\mathrm{c}}$ Blue Peter Research Centre, Cherlapally, Hyderabad, 501301, India \\ ${ }^{\mathrm{d}}$ Department of Genetics \& Molecular Medicine, Kamineni Hospitals. L.B. Nagar, Hyderabad, 500068, India \\ ${ }^{\mathrm{e}}$ Department of Pulmonology, Kamineni Hospitals. L.B. Nagar, Hyderabad, 500068, India
}

\begin{abstract}
Objective: Pulmonary tuberculosis (PTB) is a leading cause of morbidity and mortality. Macrophages play an important role in the immunopathogenesis of tuberculosis. Extracellular ATP induces macrophage bactericidal activity through activation of the purinergic P2X7 receptor. This case- control study assesses the association of -762 T/C, 1513A/C and 1729T/A P2X7 polymorphisms in patients with PTB and healthy controls to establish association if any with risk of developing the disease.

Materials and methods: The genotyping for P2X7 was carried out using PCR and RFLP analysis in 256 individuals, which included 156 active PTB patients and 100 age and sex, matched healthy volunteers with no clinical symptoms or family history of PTB as controls.

Results: A chi square test showed a significant difference between the PTB patient and controls for $-762 \mathrm{C}$ allele; $p=0.0051$ (OR 1.6972, CI 95\% 1.1839 to 2.4332) and1729 T allele was found to be positively associated with the PTB; $p<0.0005$ (OR2.4623 , CI $95 \% 1.6376$ to 3.7022 ). 1513A/C polymorphism did not show any significant difference between the two groups. Significance: The study revealed a significant association of P2X7-762C allele and P2X7 1729T allele receptor polymorphisms with PTB in Asian Indian population. The use of these alleles as biomarkers for identifying individuals at high risk of developing TB needs to be ascertained.
\end{abstract}

Keywords: Tuberculosis, P2X7 Gene polymorphisms, Mycobacterium tuberculosis, Purinergic Receptor

\section{Introduction}

Tuberculosis (TB) remains a global health burden and in humans it is mainly caused by Mycobacterium tuberculosis (M.tb) infection. Pulmonary tuberculosis (PTB) is still a leading cause of death worldwide,

\footnotetext{
* Corresponding author: Dr. Q. Hasan, Senior Consultant, Department of Genetics and Molecular Medicine, Kamineni Hospital, L.B. Nagar, Hyderabad- 500068, India. Tel.: +91 402402227276 Ext: 210; Fax: +91 40 24022277; E-mail: qhasan2000@yahoo.com.
}

and the incidence of the disease has been reported to have increased since 1980. India accounts for a fifth of the world's new TB cases with 1.8 million being diagnosed annually [1]. Almost a third of the world's population is infected with $M$. $t b$, however, only $5-15 \%$ of those who have been infected develop clinical TB during their lifetime [2,3]. It is considered that genes regulating the immune response confer susceptibility to active disease $[4,5]$.

Macrophages, the principal host cells for intracellular replication of mycobacteria, play an important role 
Table 1

Details of the primers used for the P2X7 polymorphisms studied. The conditioned for PCR along with the target amplicon size and restriction enzymes used

\begin{tabular}{|c|c|c|c|c|}
\hline $\begin{array}{l}\text { P2X7 } \\
\text { polymorphisms }\end{array}$ & Primer sequences $\left(5^{\prime}-3^{\prime}\right)$ & $\begin{array}{l}\text { Annealing } \\
\text { temp. }\end{array}$ & $\begin{array}{l}\text { Detection } \\
\text { method }\end{array}$ & $\begin{array}{l}\text { Amplicon } \\
\text { size (bp) }\end{array}$ \\
\hline$-762 \mathrm{C} / \mathrm{T}$ & $\begin{array}{l}\text { ATGTGCGTAGCTCTTCTGGTG } \\
\text { GGCAGGTCGATCTATGACCTA }\end{array}$ & $59^{\circ} \mathrm{C}$ & $\begin{array}{l}\text { Hinc II } \\
15 \% \text { PAGE }\end{array}$ & $126 / 80 / 46$ \\
\hline $1513 \mathrm{~A} / \mathrm{C}$ & $\begin{array}{l}\text { AGACCTACGATGGACTTCACAG } \\
\text { AGCGCCAGCAAGGGCTC [17] }\end{array}$ & $56^{\circ} \mathrm{C}$ & $\begin{array}{l}\text { Hae II, } 2 \% \\
\text { agarose }\end{array}$ & $\begin{array}{l}316 / 200 / \\
119\end{array}$ \\
\hline 1729 T/A & $\begin{array}{l}\text { CTGGATGTGGATTCCACCAA- } \\
\text { AAACTCTTTCCGGATCCTCCA' }\end{array}$ & $56^{\circ} \mathrm{C}$ & $\begin{array}{l}\text { BtsCI, } \\
15 \% \text { PAGE }\end{array}$ & $138 / 90 / 48$ \\
\hline
\end{tabular}

in controlling the infection. They act as antigen presenting cells during reactivation of lymphocytes at the sites of infection [6]. Extracellular ATP induces the bacteriocidal activity of macrophages through activation of the $\mathrm{P} 2 \mathrm{X} 7$ purinergic receptor, this leads to apoptosis of the macrophage, which serve as an important host defense mechanism against $M$. $t b$ infection [7].

Various gene polymorphisms of the $\mathrm{P} 2 \mathrm{X} 7$ receptor have been identified which affect its function and have been associated with a number of diseases including TB [8-10]. Several genetic polymorphisms have been studied in association with TB in Indian population but to the best of our knowledge there are no studies associating $\mathrm{P} 2 \mathrm{X} 7$ polymorphisms with TB $[11,12]$. Hence, this case - control study assessed three polymorphisms of P2X7: (i) $-762 \mathrm{~T} / \mathrm{C}$ promoter polymorphism, (ii) A1513C (rs3751143) and (iii) T1729A (rs1653624) polymorphisms in Indian PTB patients.

\section{Materials and methods}

PTB patients who attended two hospitals in Hyderabad, a cosmopolitan city of south India were enrolled in this study (Refer Acknowledgement). A total of 256 individuals were assessed after obtaining written consent from each subject. This includes 156 unrelated newly diagnosed active PTB patients confirmed by sputum smear positive for $M$. $t b$ and Chest $\mathrm{X}$-ray findings according to World Health Organization (WHO)/Renewed National Tuberculosis Control Programme (RNTCP) norm [1,2]. Hundred age and sex matched healthy unrelated volunteers with no clinical symptoms or family history of TB were taken as controls. The study was approved by the institutional ethical committee. Detailed clinical and family history was collected in a well-designed Proforma. One ml peripheral blood was taken and genomic DNA was isolated by the method routinely followed in our lab [13].

The three P2X7 gene polymorphisms were analyzed with PCR followed by Restriction fragment length polymorphism (RFLP) and electrophoresis. Briefly genotyping was carried out by a 3-step PCR in Xp thermal-cycler (Hangzhow, China) at $94^{\circ} \mathrm{C}$ for $3 \mathrm{~min}$ utes followed by 35 cycles at $94{ }^{\circ} \mathrm{C}$ for 30 seconds, annealing at specific temperatures for 30 seconds and extension at $72^{\circ} \mathrm{C}$ for 45 seconds and a final extension at $72^{\circ} \mathrm{C}$ for 5 minutes was carried out [13].

The primers for $-762 \mathrm{C} / \mathrm{T}$ and $1729 \mathrm{~T} / \mathrm{A}$ polymorphism were designed using Primer 3 Input software version 3.1 while the primers for $1513 \mathrm{~A} / \mathrm{C}$ was based on an earlier report and their details are given in Table 1 [8]. Primers sets were synthesized by MWG (Bangalore, India). Hinc II and Hae II were procured from Fermentas (Bulington, Ontario, Canada) and BstCI from New England Biolabs, (Ipswish, Suffolk, UK). PCR product analysis was done on $2 \%$ agarose gel while RFLP products were visualized after silver staining of $15 \%$ Poly acrylamide gel electrophoresis (PAGE). Genotyping of $\mathrm{P} 2 \mathrm{X} 7-762 \mathrm{C} / \mathrm{T}$ polymorphism was done by digesting the $126 \mathrm{bp}$ PCR product with Hinc II, while 1729T/A was genotyped with BtsCI. The genotyping for $1513 \mathrm{~A} / \mathrm{G}$ was carried out as described by $\mathrm{Li}$ et al. [17].

Chi square test was used for comparison of expected and observed frequencies of categorical variables. Values of p (two - tailed) less than 0.05 were considered statistically significant. Odds ratio was calculated. Statistical analysis was performed using MedCalc for Windows, version 7.4.1.0 (MedCalc Software, Mariakerke, Belgium).

\section{Results}

The mean age of PTB patients and controls was 30.4 \pm 18.3 years and $35.6 \pm 13.3$ years, respectively. Out of 156 PTB patients $50.7 \%$ were male and $49.4 \%$ female, while $57 \%$ males and $43 \%$ females were in the control group.

Genotyping of $\mathrm{P} 2 \mathrm{X} 7-762 \mathrm{C} / \mathrm{T}$ polymorphism; 80 and 46bp fragments indicated a homozygous CC geno- 
Table 2

Comparison of frequency distribution of $\mathrm{P} 2 \mathrm{X} 7-762 \mathrm{C} / \mathrm{T}$ genotypes and alleles in pulmonary tuberculosis patients and controls in the present study with other studies

\begin{tabular}{|c|c|c|c|c|c|c|c|c|c|c|c|c|c|}
\hline \multirow{3}{*}{$\begin{array}{l}\text { Population } \\
\text { studied }\end{array}$} & \multicolumn{5}{|c|}{ PTB patients } & \multicolumn{6}{|c|}{ Controls } & \multirow{3}{*}{$\begin{array}{l}\mathrm{P} \\
\text { value }\end{array}$} & \multirow{3}{*}{$\begin{array}{r}\text { Ref. } \\
\text { No }\end{array}$} \\
\hline & \multicolumn{3}{|c|}{ Genotype (\%) } & \multicolumn{2}{|c|}{ Allele } & & \multicolumn{3}{|c|}{ Genotype(\%) } & \multicolumn{2}{|c|}{ Allele } & & \\
\hline & $\mathrm{CC}$ & $\mathrm{TC}$ & TT & $\mathrm{C}$ & $\mathrm{T}$ & & $\mathrm{CC}$ & CT & TT & $\mathrm{C}$ & $\mathrm{T}$ & & \\
\hline $\begin{array}{l}\text { Gambian PTB } \\
(n=323)\end{array}$ & $\begin{array}{l}23 \\
(7.1)\end{array}$ & $\begin{array}{l}118 \\
(36.5)\end{array}$ & $\begin{array}{l}182 \\
(56.3)\end{array}$ & 0.25 & 0.75 & $n=347$ & $\begin{array}{l}44 \\
(12.7)\end{array}$ & $\begin{array}{l}141 \\
(40.3)\end{array}$ & $\begin{array}{l}163 \\
(47)\end{array}$ & 0.33 & 0.67 & 0.003 & 17 \\
\hline $\begin{array}{l}\text { Mexican PTB } \\
(n=92)\end{array}$ & $\begin{array}{l}8 \\
(8.5)\end{array}$ & $\begin{array}{l}32 \\
(34.04)\end{array}$ & $\begin{array}{l}52 \\
(57.45)\end{array}$ & 0.25 & 0.75 & $n=110$ & $\begin{array}{l}15 \\
(13.64)\end{array}$ & $\begin{array}{l}44 \\
(40)\end{array}$ & $\begin{array}{l}51 \\
(46.3)\end{array}$ & 0.34 & 0.66 & 0.075 & 19 \\
\hline $\begin{array}{l}\text { Russian PTB } \\
(n=190)\end{array}$ & $\begin{array}{l}86 \\
(45.3)\end{array}$ & $\begin{array}{l}87 \\
(45.8)\end{array}$ & $\begin{array}{l}17 \\
(8.9)\end{array}$ & 0.68 & 0.32 & $n=127$ & $\begin{array}{l}65 \\
(51.2)\end{array}$ & $\begin{array}{l}46 \\
(36.2)\end{array}$ & $\begin{array}{l}16 \\
(12.6)\end{array}$ & 0.70 & 0.30 & 0.800 & 20 \\
\hline $\begin{array}{l}\text { Chinese } \\
\text { Hans PTB } \\
(n=38)\end{array}$ & $\begin{array}{l}23 \\
(60.5)\end{array}$ & $\begin{array}{l}11 \\
(28.9)\end{array}$ & $\begin{array}{l}4 \\
(10.5)\end{array}$ & 0.75 & 0.25 & $n=384$ & $\begin{array}{l}208 \\
(54.2)\end{array}$ & $\begin{array}{l}135 \\
(35.2)\end{array}$ & $\begin{array}{l}41 \\
(10.7)\end{array}$ & 0.72 & 0.28 & $\begin{array}{l}0.546 \\
\& \\
0.262\end{array}$ & 21 \\
\hline $\begin{array}{l}\text { Chinese Hans } \\
\text { EP TB } \\
(n=58)\end{array}$ & $\begin{array}{l}40 \\
(69)\end{array}$ & $\begin{array}{l}12 \\
(20.7)\end{array}$ & $\begin{array}{l}6 \\
(10.3)\end{array}$ & 0.77 & 0.23 & & & & & & & & \\
\hline $\begin{array}{l}\text { Our Study } \\
(n=156)\end{array}$ & $\begin{array}{l}38 \\
(24.3)\end{array}$ & $\begin{array}{l}88 \\
(56.4)\end{array}$ & $\begin{array}{l}30 \\
(19.23)\end{array}$ & $0.53 *$ & 0.47 & $n=100$ & $\begin{array}{l}15 \\
(15)\end{array}$ & $\begin{array}{l}49 \\
(49)\end{array}$ & $\begin{array}{l}36 \\
(36)\end{array}$ & $0.40^{*}$ & 0.60 & & \\
\hline
\end{tabular}

$* \chi^{2}=0.0051$ and OR $=1.6972(\mathrm{CI} 95 \% 1.1839$ to2.4332) between Pulmonary TB subjects and controls.

Table 3

Comparison of frequency distribution of P2X7 1513A/C genotypes and alleles in pulmonary tuberculosis patients and controls in the present study with other studies

\begin{tabular}{|c|c|c|c|c|c|c|c|c|c|c|c|c|c|}
\hline \multirow{3}{*}{$\begin{array}{l}\text { Population } \\
\text { studied }\end{array}$} & \multicolumn{5}{|c|}{ PTB patients } & \multicolumn{6}{|c|}{ Controls } & \multirow{3}{*}{$\begin{array}{l}\mathrm{P} \\
\text { value }\end{array}$} & \multirow{3}{*}{$\begin{array}{r}\text { Ref. } \\
\text { No }\end{array}$} \\
\hline & \multicolumn{3}{|c|}{ Genotype (\%) } & \multicolumn{2}{|c|}{ Allele } & & \multicolumn{3}{|c|}{ Genotype(\%) } & \multicolumn{2}{|c|}{ Allele } & & \\
\hline & AA & $\mathrm{AC}$ & $\mathrm{CC}$ & $\mathrm{A}$ & $\mathrm{C}$ & & AA & $\mathrm{AC}$ & $\mathrm{CC}$ & $\mathrm{A}$ & $\mathrm{C}$ & & \\
\hline $\begin{array}{l}\text { Gambian PTB } \\
(n=325)\end{array}$ & $\begin{array}{l}261 \\
(80.3)\end{array}$ & $\begin{array}{l}58 \\
(17.8)\end{array}$ & $\begin{array}{l}6 \\
(1.8)\end{array}$ & 0.89 & 0.11 & $n=297$ & $\begin{array}{l}256 \\
(86.2)\end{array}$ & $\begin{array}{l}37 \\
(12.5)\end{array}$ & $\begin{array}{l}4 \\
(1.3)\end{array}$ & 0.92 & 0.08 & 0.117 & 17 \\
\hline $\begin{array}{l}\text { Mexican PTB } \\
(n=94)\end{array}$ & $\begin{array}{l}53 \\
(75.9)\end{array}$ & $\begin{array}{l}33 \\
(22.9)\end{array}$ & $\begin{array}{l}8 \\
(12.2)\end{array}$ & 0.88 & 0.12 & $n=110$ & $\begin{array}{l}70 \\
(63.4)\end{array}$ & $\begin{array}{l}38 \\
(34.55)\end{array}$ & $\begin{array}{l}2 \\
(1.82)\end{array}$ & 0.81 & 0.19 & 0.02 & 19 \\
\hline $\begin{array}{l}\text { Russian PTB } \\
(n=188)\end{array}$ & $\begin{array}{l}120 \\
(63.8)\end{array}$ & $\begin{array}{l}59 \\
(31.4)\end{array}$ & $\begin{array}{l}9 \\
(4.8)\end{array}$ & 0.80 & 0.20 & $n=126$ & $\begin{array}{l}96 \\
(76.2)\end{array}$ & $\begin{array}{l}27 \\
(21.4)\end{array}$ & $\begin{array}{l}3 \\
(2.4)\end{array}$ & 0.87 & 0.13 & 0.856 & 20 \\
\hline $\begin{array}{l}\text { Australian PTB } \\
(n=56)\end{array}$ & $\begin{array}{l}34 \\
(60)\end{array}$ & $\begin{array}{l}17 \\
(30.3)\end{array}$ & $\begin{array}{l}5 \\
(9.7)\end{array}$ & 0.75 & 0.25 & $n=167$ & $\begin{array}{l}105 \\
(62.8)\end{array}$ & $\begin{array}{l}55 \\
(33.3)\end{array}$ & $\begin{array}{l}7 \\
(4.19)\end{array}$ & 0.79 & 0.21 & $\begin{array}{l}0.94 \\
\& \\
<0.01\end{array}$ & 18 \\
\hline $\begin{array}{l}\text { Australian } \\
\text { Extra PTB } \\
(n=30)\end{array}$ & $\begin{array}{l}9 \\
(30)\end{array}$ & $\begin{array}{l}17 \\
(56.6)\end{array}$ & $\begin{array}{l}4 \\
(13.3)\end{array}$ & 0.58 & 0.42 & & & & & & & & \\
\hline $\begin{array}{l}\text { Chinese Hans } \\
\text { PTB }(n=38)\end{array}$ & $\begin{array}{l}21 \\
(51.2)\end{array}$ & $\begin{array}{l}18 \\
(43.9)\end{array}$ & $\begin{array}{l}2 \\
(4.9)\end{array}$ & 0.73 & 0.27 & $n=384$ & $\begin{array}{l}221 \\
(57.6)\end{array}$ & $\begin{array}{l}119 \\
(31)\end{array}$ & $\begin{array}{l}44 \\
(11.4)\end{array}$ & 0.73 & 0.27 & $\begin{array}{l}0.981 \\
\& \\
0.868\end{array}$ & 21 \\
\hline $\begin{array}{l}\text { Chinese Hans } \\
\text { EP TB }(n=58)\end{array}$ & $\begin{array}{l}30 \\
(54.5)\end{array}$ & $\begin{array}{l}19 \\
(34.5)\end{array}$ & $\begin{array}{l}6 \\
(10.9)\end{array}$ & 0.72 & 0.28 & & & & & & & & \\
\hline $\begin{array}{l}\text { Our Study } \\
(n=156)\end{array}$ & $\begin{array}{l}89 \\
(57)\end{array}$ & $\begin{array}{l}55 \\
(35.3)\end{array}$ & $\begin{array}{l}12 \\
(7.7)\end{array}$ & 0.74 & 0.26 & $n=100$ & $\begin{array}{l}71 \\
(71)\end{array}$ & $\begin{array}{l}21 \\
(21)\end{array}$ & $\begin{array}{l}8 \\
(8)\end{array}$ & 0.82 & 0.18 & 0.0909 & \\
\hline
\end{tabular}

type, while CT heterozygotes showed 126, 80 and 46 bp fragments and TT homozygotes had only the 126 bp band when visualized on PAGE. The genotype and allele frequencies for the $-762 \mathrm{C} / \mathrm{T}$ polymorphism are given in the Table 2. The chi square between the PTB patient and control group was significant for $-762 \mathrm{C}$ allele $(p=0.0051)$ and a dominant mode of analysis for genotype $(\mathrm{CC}+\mathrm{CT})$ showed a significant difference $(p=0.004)$. The $-762 \mathrm{C}$ allele was significantly associated with PTB in the cohort of patients from our population (OR 1.6972, CI 95\% 1.1839 to 2.4332).
Genotyping of P2X7 1513A/C polymorphism; an uncut PCR product of $319 \mathrm{bp}$ for AA genotype, while 200 and $119 \mathrm{bp}$ fragments indicated CC genotype and heterozygote had all three bands. The genotype and allele frequencies for the $1513 \mathrm{~A} / \mathrm{C}$ polymorphism in patients and controls are shown in Table 3. A statistical analysis did not show association of this polymorphism with PTB.

Genotyping of P2X7 1729T/A polymorphism; the uncut product of $138 \mathrm{bp}$ indicated TT genotype and a $138 \mathrm{bp}, 98 \mathrm{bp}$ and 40bp indicated TA heterozygous, 
Table 4

Frequency of P2X7 1729T/A genotype and allele frequencies in the studies in which it was assessed

\begin{tabular}{|c|c|c|c|c|c|c|c|c|c|c|c|c|c|}
\hline \multirow{3}{*}{$\begin{array}{l}\text { Population } \\
\text { studied }\end{array}$} & \multicolumn{5}{|c|}{ Cases } & \multicolumn{6}{|c|}{ Controls } & \multirow{3}{*}{$\begin{array}{c}\mathrm{P} \\
\text { value }\end{array}$} & \multirow{3}{*}{$\begin{array}{r}\text { Ref. } \\
\text { No }\end{array}$} \\
\hline & \multicolumn{3}{|c|}{ Genotype (\%) } & \multicolumn{2}{|c|}{ Allele } & & \multicolumn{3}{|c|}{ Genotype(\%) } & \multicolumn{2}{|c|}{ Allele } & & \\
\hline & TT & TA & $\mathrm{AA}$ & $\mathrm{T}$ & $\mathrm{A}$ & & TT & TA & AA & $\mathrm{T}$ & $\mathrm{A}$ & & \\
\hline $\begin{array}{l}\text { Australian } \\
\text { (CLL) } \\
(n=45)\end{array}$ & $\begin{array}{l}42 \\
(93.4)\end{array}$ & $\begin{array}{l}3 \\
(6.6)\end{array}$ & & 0.97 & 0.03 & $(n=85)$ & $\begin{array}{l}82 \\
(96.6)\end{array}$ & $\begin{array}{l}3 \\
(3.4)\end{array}$ & & 0.963 & 0.037 & 0.73 & 10 \\
\hline $\begin{array}{l}\text { American } \\
(n=1764) \\
\text { Postmenopa } \\
\text { woman }\end{array}$ & & & & & & & $\begin{array}{l}1646 \\
(93.3)\end{array}$ & $\begin{array}{l}117 \\
(6.6)\end{array}$ & $\begin{array}{l}1 \\
(0.1)\end{array}$ & 0.97 & 0.03 & - & 23 \\
\hline $\begin{array}{l}\text { Our study } \\
\text { PTB } \\
(n=156)\end{array}$ & $\begin{array}{l}99 \\
(63.46)\end{array}$ & $\begin{array}{l}57 \\
(36.54)\end{array}$ & & $0.81 *$ & 0.19 & $(n=100)$ & $\begin{array}{l}29 \\
(29)\end{array}$ & $\begin{array}{l}71 \\
(71)\end{array}$ & & $0.64 *$ & 0.36 & & \\
\hline
\end{tabular}

$* \chi^{2}<0.0001$ and $\mathrm{OR}=2.4623(\mathrm{CI} 95 \% 1.6376$ to 3.7022$)$ between Pulmonary TB subjects and controls.

while $98 \mathrm{bp}$ and $40 \mathrm{bp}$ bands indicate AA genotype. The genotype and allele frequencies for the 1729T/A polymorphism in patients and controls are shown in Table 4. The $1729 \mathrm{~T}$ allele was found to be positively associated with the PTB (OR-2.4623, CI 95\% 1.6376 to 3.7022, $p<0.0005)$. The AA genotype was not identified in any of the patients and controls from Indian population.

\section{Discussion}

$\mathrm{P} 2 \mathrm{X} 7$ receptor is a ligand-gated channel, selective for cationic permeants, it has a wide distribution on human cells including those of the immune system especially macrophage and hemopoietic system $[14,15]$. The human P2X7 gene is located on chromosome $12 \mathrm{q} 24.31$ and consists of 13 exons, with exon 12 and 13 coding for the C-terminal tail of this molecule [16]. After ATP activation this receptor opens a channel that allows a cascade of intracellular downstream events which lead to the apoptosis of the target cell. The expression of this receptor is further up-regulated by Interferon- gamma (IFN- $\gamma$ ), an important cytokine playing a major role in the inflammatory process seen in TB infection. Various gene polymorphisms like $-762 \mathrm{C} / \mathrm{T}, 1513 \mathrm{~A} / \mathrm{C}$ and 1729 T/A in P2X7 receptor gene have been reported, some have been associated with TB in different ethnic groups $[8-10,17,18]$. This is the first report from India on all three P2X7 gene polymorphisms and their association with PTB.

The result from the present study suggests a positive association of $\mathrm{P} 2 \mathrm{X} 7-762 \mathrm{C} / \mathrm{T}$ polymorphism with PTB. There are four reports on $\mathrm{P} 2 \mathrm{X} 7-762 \mathrm{C} / \mathrm{T}$ polymorphism in PTB with Gambian, Mexican, Russian and Chinese Han populations [17,18,20,21]. The frequency of T allele in controls is 0.6 in our study which is similar to that of Gambian (0.67) and Mexican (0.66) populations but is two-fold higher than the frequency of T allele reported for the Russian (0.30) and Chinese Han (0.28) population. This shows that $\mathrm{T}$ allele may have been favored during evolution in this region akin to the prevalence of the sickle cell anemia allele in African and Mediterranean populations where malaria is highly prevalent [22]. The-762 promoter polymorphism falls in the region where various transcription factors tend to bind [17]. Thus, sequence changes in promoter region may influence the activity of $\mathrm{P} 2 \mathrm{X} 7$ receptor expression and alters its ability to regulate macrophage activity which helps in controlling TB infection $[17$, 19]. The variations observed in the allele frequency for $\mathrm{P} 2 \mathrm{X} 7-762 \mathrm{C} / \mathrm{T}$ polymorphism in different ethnic groups explains the survival advantage over TB infection [22]. The result from the present study suggests a significant association between $\mathrm{P} 2 \mathrm{X} 7-762 \mathrm{C}$ allele with PTB (OR 1.6972, CI 95\% 1.1839 to 2.4332). The other three studies did not show any association with PTB patients.

The frequency of genotypes and alleles for P2X7 1513 polymorphism appears to be similar across most populations as is seen in the controls from five ethnic groups including ours. However, the Gambian population has the lowest 1513C allele frequency [17]. Analysis from the present study shows no association of either genotype or allele with the PTB, similar result was observed in studies from Gambian, Chinese Hans and Australian PTB patients. However, a positive association of 1513C allele was reported with PTB in Russian and Mexican population and Extra-pulmonary TB in Australian-Vietnamese population [17-20]. This polymorphism does not seem be associated with PTB in Indian population; however, studies on extra-pulmonary TB are warranted. 
The P2X7 1729T/A gene polymorphism did not follow the Hardy- Weinberg equilibrium $(\mathrm{P}>0.05)$, since the AA genotype was not detected in any of the 256 individuals analyzed in the present study. Similarly a study from Australia ( $n=130$ ) did not identify any individuals with AA genotype [10]. However, a recent study from USA by Ohlendroff et al. [23] on a large sample $(n=1764)$ revealed AA genotype in one individual $(<0.05 \%)$ [23]. This polymorphism results in loss of receptor trafficking and thereby affecting the receptor expression. All these observations suggest that the AA genotype may have a deleterious effect and persons with this genotype may fail to survive. The other possibility is that they may develop neuronal problems since P2X7 is said to play a major role in neural development during embryogenesis [15]. It is surprising that the A allele is 13 times higher than what is reported in American and Australian population and this needs to be investigated [13,23]. The P2X7 $1729 \mathrm{~T}$ allele was found to be significantly associated with PTB (OR 2.4623, CI 95\% 1.6376 to 3.7022). This is the first study reporting association of $\mathrm{P} 2 \mathrm{X} 71729 \mathrm{~T} / \mathrm{A}$ polymorphism with an infectious disease like tuberculosis.

In conclusion, our study revealed a significant association of two $\mathrm{P} 2 \mathrm{X} 7$ receptor polymorphisms with $\mathrm{PTB}$ in our population. The $-762 \mathrm{C}$ and $1729 \mathrm{~T}$ alleles may be used as biomarkers for identifying contacts at high risk (family members and health personnel, who are taking care of PTB) and putting them on surveillance thereby helping in reducing the incidence of PTB.

\section{Acknowledgements}

We acknowledge the help of the DOTS unit of BMMRC and Department of Pulmonology, Kamineni Hospital for providing samples. We thank Ms. Manorama for her kind cooperation in sample collection. We would like to thank DBT, Govt. of India for funding the project (BT/PR5828/med/14/702/2005).

\section{References}

[1] TB India 2008 - RNTCP status report. RNTCP, 2008.

[2] World Health Organization. Global tuberculosis control: surveillance, planning, financing. WHO report 2008. Geneva, World Health Organization 2008.

[3] P.E. Smith and A.R. Moss, Epidemiology of tuberculosis, in: Tuberculosis: Pathogenesis, Protection, and Control, B.R. Bloom, ed., Am. Soc. Microbiol., Washington DC, 1994, pp. 47-66.
[4] D. Lykouras, F. Sampsonas, A. Kaparianos, K. Karkoulias, G. Tsoukalas and K. Spiropoulos, Human genes in TB infection: their role in immune response, Monaldi Arch Chest Dis 69 (2008), 24-31.

[5] W.J. Britton, S.L. Fernando, B.M. Saunders, R. Sulter and J.S. Wiley, The gentic control of susceptibility to Mycobacterium tuberculosis, Novartis found Symp 281 (2007), 79-89.

[6] C. Manca, S. Paul, C.E. Barry, V.H. Freedman and G. Kaplan, Mycobacterium tuberculosis catalase and peroxidase activities and resistance to oxidative killing in human monocytes in vitro, Infect Immun 67 (1999), 74-79.

[7] I.P. Fairbairn, C.B. Stober, D.S. Kumararatne and D.A. Lammas. ATP-mediated killing of intracellular mycobacteria by macrophages is a $\mathrm{P} 2 \mathrm{X}(7)$-dependent process inducing bacterial death by phagosome-lysosome fusion, J Immunol 167 (2001), 3300-3307.

[8] B.J. Gu, W. Zhang, R.A. Worthington, R. Sluyter, P. Dao-Ung, S. Petrou, J.A. Barden and J.S. Wiley, A Glu-1513 to Ala polymorphism leads to loss of function of the human $\mathrm{P} 2 \mathrm{X}_{7}$ receptor, J Biol Chem 276 (2001), 11135-11142.

[9] B.J. Gu, R. Sluyter, K.K. Skarratt, A.N. Shemon, L.P. DaoUng, S.J. Fuller, J.A. Barden, A.L. Clarke, S. Petrou and J.S. Wiley. An $\mathrm{Arg}^{307}$ to Gln polymorphism within the ATPbinding site causes loss of function of the human $\mathrm{P}_{2} \mathrm{X}_{7}$ receptor, J Biol Chem 279 (2004), 31287-31295.

[10] J.S. Wiley, L.P. Dao-Ung, C. Li, A.N. Shemon, B.J. Gu, M.L. Smart, S.J. Fuller, J.A. Barden, S. Petrou and R. Sluyter. An Ile-568 to Asn polymorphism prevents normal trafficking and function of the human P2X7 receptor, J Biol Chem 278 (2003), 17108-17113.

[11] B. Anuradha, S. Rakh, Md. Ishaq, K. Murthy and V. Valluri, Interferon- gamma Low producer genotype +874 overexpressed in Bacillus Calmette-Guein non-responding children, Pediatr Infec Dis J 27 (2008), 325-329.

[12] P. Selvaraj, K. Alagarasu, M. Harishankar, M. Vidyarani and P.R. Narayanan, Regulatory region polymorphisms of vitamin $D$ receptor gene in pulmonary tuberculosis patients and normal healthy subjects of south India, Int J Immunogenet 35 (2008), 251-254.

[13] R.V. Alluri, V. Mohan, S. Komandur, K. Chawda, J.R. Chaudhuri and Q. Hasan, MTHFR C677T gene mutation as a risk factor for arterial stroke: A hospital based study, Eur J Neu 12 (2005), 40-44.

[14] F. Di Virgilio, P. Chiozzi, D. Ferrari, S. Falzoni, J.M. Sanz, A. Morelli, M. Torboli, G. Bolognesi and O.R. Baricordi, Nucleotide receptors: an emerging family of regulatory molecules in blood cells, Blood 3 (2001), 587-600.

[15] R.A. North, Molecular Physiology of P2X Receptors, Physiol Rev 82 (2002), 1013-1067.

[16] A. Supernant, F. Rassendren, E. Kawashima, R.A. North and G. Buell, The cytolytic P2Z receptor for extracellular ATP identified as a P2X receptor (P2X7), Science 272 (1996), 735738.

[17] C.M. Li, S.J. Campbell, D.S. Kumararatne, R. Bellamy, C. Ruwende, K. P. McAdam, A.V. Hill and D. A. Lammas. Association of a polymorphism in the P2X7 gene with tuberculosis in a Gambian population, J Inf Diseases 186 (2002), 1458-1462.

[18] S.L. Fernando, B.M. Saunders, R. Sluyter, K.K. Skarratt, H. Goldberg, G.B. Marks, J.S. Wiley and W.J. Britton, A polymorphism in the $\mathrm{P}_{2} \mathrm{X}_{7}$ gene increases susceptibility to extrapulmonary tuberculosis, Ame J Res and Critical Care Medicine 175 (2007), 360-366. 
[19] P. Niño-Moreno, D. Portales-Pérez, B. Hernández-Castro, L. Portales-Cervantes, V. Flores-Meraz, L. Baranda, A. GómezGómez, V. Acuña-Alonzo, J. Granados and R. GonzálezAmaro, P2X7 and NRAMP1/SLC11A1 gene polymorphism in Mexican mestizo patients with pulmonary tuberculosis, Clin Ехр Ітти 148 (2007), 469-477.

[20] I. Mokrousov, N. Sapozhnikova and O. Narvskaya, Mycobacterium tuberculosis co-existence with human: making an imprint on the macrophage $\mathrm{P} 2 \mathrm{X} 7$ receptor gene?, J Med Micro 57 (2008), 581-584.

[21] J. Xiao, L. Sun, W. Jiao, Z. Li, S. Zhao, H. Li, J. Jin, A. Jiao, Y.
Guo, Z. Jiang, I. Mokrousov and A. Shen, Lack of association between polymorphisms in the $\mathrm{P} 2 \mathrm{X} 7$ gene and tuberculosis in a Chinese Han population, FEMS Immunol Med Microbiol 55 (2009), 107-111.

[22] A.C. Allison, Two lessons from the interface of genetics and medicine, Gent 166 (2004), 1591-1599.

[23] S.D. Ohlendorff, C.L. Tofteng, J.E. Jensen, S. Petersen, R. Civitelli, M. Fenger, B. Abrahamsen, A.P. Hermann, P. Eiken and N.R. Jørgensen, Single nucleotide polymorphism in the $\mathrm{P} 2 \mathrm{X} 7$ gene is associated to fracture risk and to effect of estrogen treatment. PhamGene Geno, 17 (2007), 555-567. 


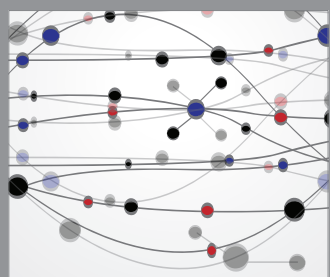

The Scientific World Journal
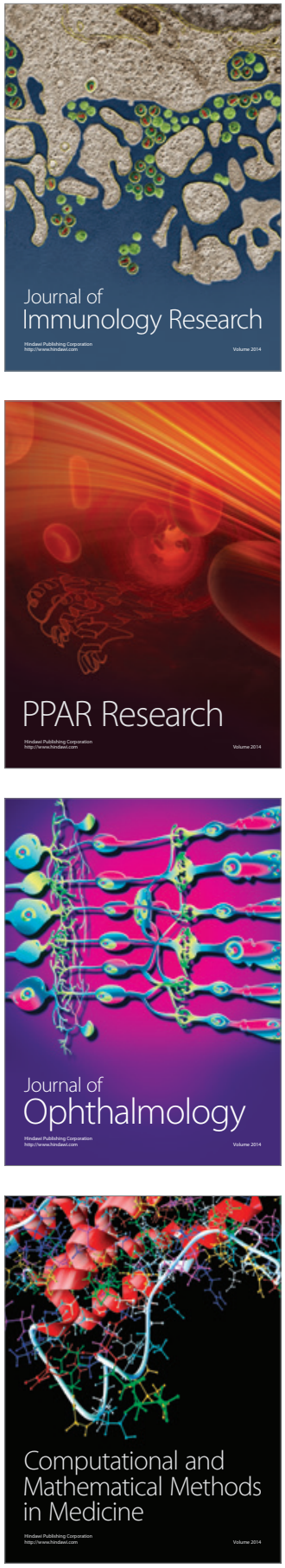

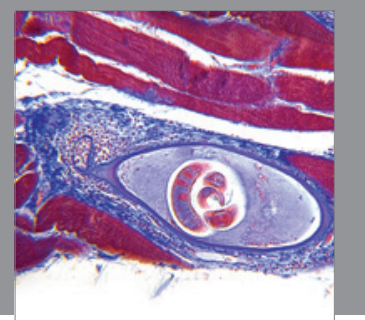

Gastroenterology

Research and Practice
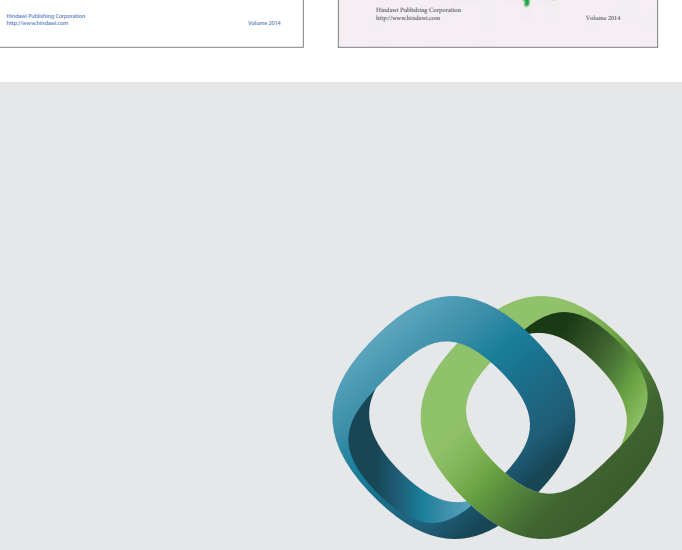

\section{Hindawi}

Submit your manuscripts at

http://www.hindawi.com
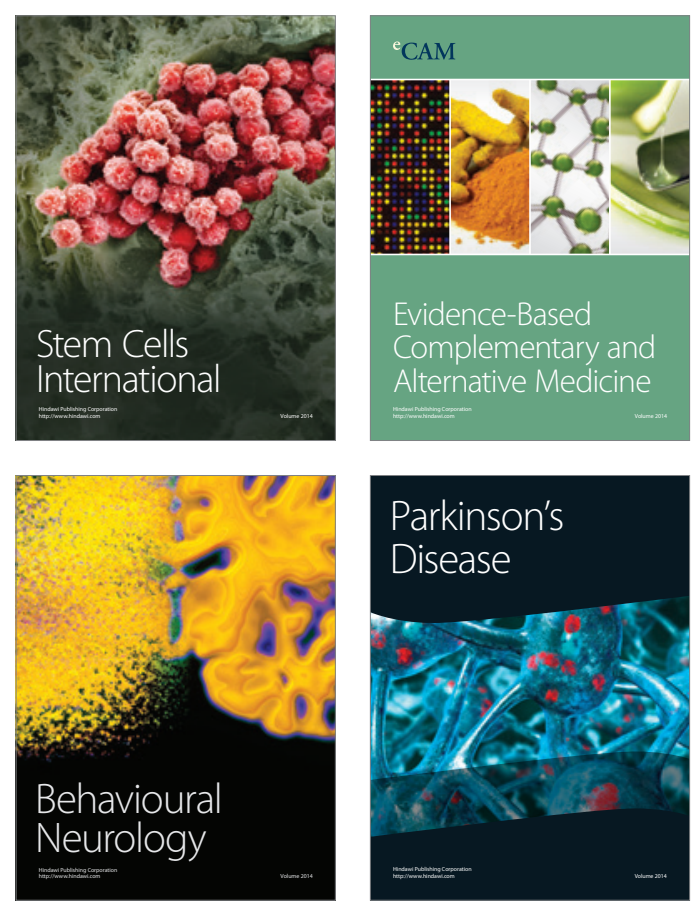

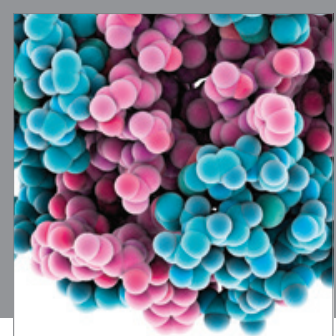

Journal of
Diabetes Research

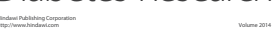

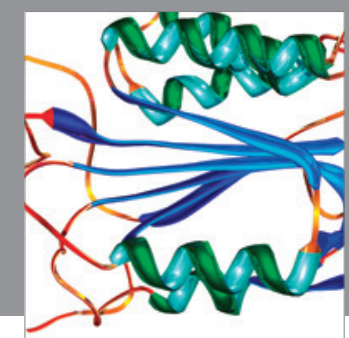

Disease Markers
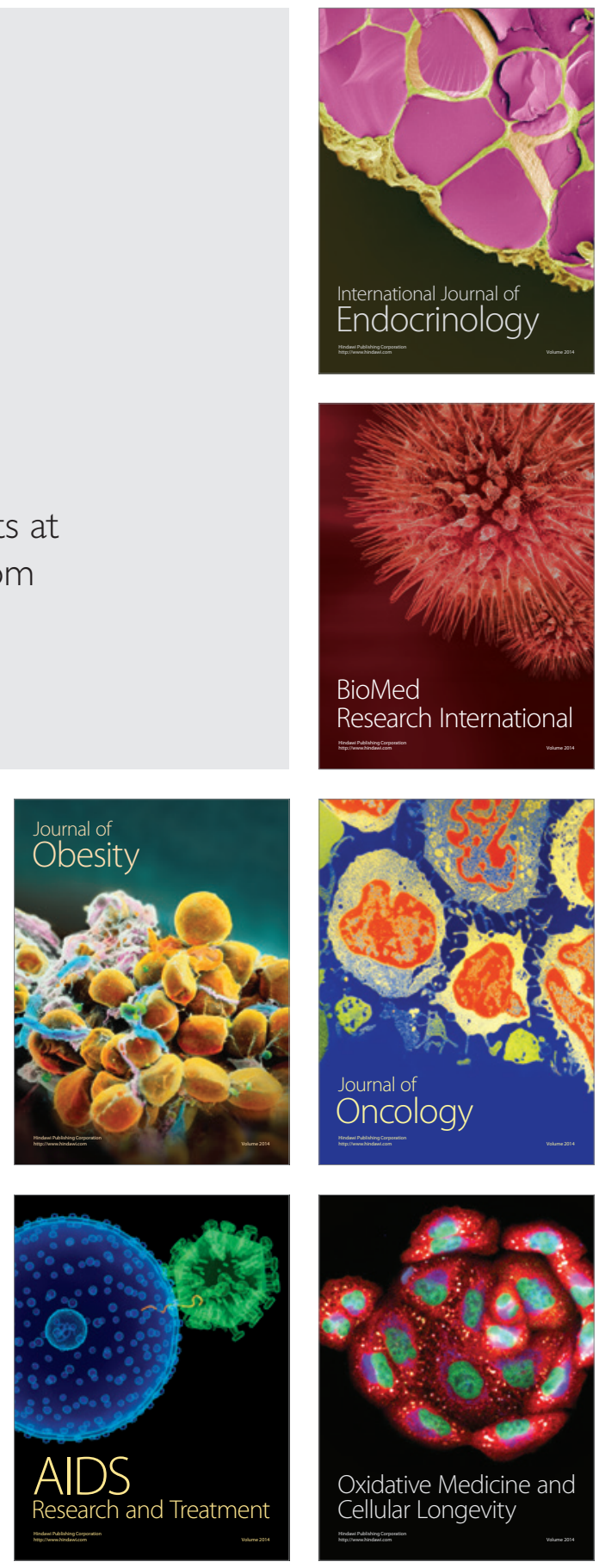